\title{
Path Analysis: Effects of Psychological and Socio-Economic Exposures During Gestational Period on the Risk of Under Nutrition in Children Under Five
}

\author{
Yespy Anna Wahyu Nurindahsari'1), Bhisma Murti²), Eti Poncorini Pamungkasari3)
}

\author{
${ }^{1)}$ School of Health Sciences, STIKes Guna Bangsa, Yogyakarta \\ ${ }^{2)}$ Masters Program in Public Health, Universitas Sebelas Maret \\ 3)Faculty of Medicine, Universitas Sebelas Maret
}

\begin{abstract}
Background: In Indonesia the prevalence of under nutrition in children under five in2013 was estimated to be12.2\%. It is estimated that there are still 4.5 million children under five with under or poor nutrition have not been detected. Poor nutrition in children under five may have serious impact on their health outcome and cognitive ability in later life. This study aimed to investigate the effects of psychological and socio-economic exposure during gestational period and geographical area on the risk of under nutrition in children under five.

Subjects and method: This was an analytical observational using case-control design. This study was conducted in Klaten, Central Java, from 8 September to 2 December 2016. A total of 150 subjects consisting of 57 children under five with birth weight $<2,500 \mathrm{~g}$ and 93 children under five with birth weight $\geq 2,500 \mathrm{~g}$, were selected by fixed exposure sampling. The dependent variable was weight for age. The independent variable included maternal education, family income, number of children, middle upper arm circumference (MUAC), maternal gestational stress, slow fetal growth for gestational age, low birth weight, nutritional intake, geographic area. The data were collected by a set of questionnaire, 24 hours food recall, and medical record. The data were analyzed using path analysis.

Results: Nutritional intake that is lower than recommended allowance $(b=3.14 ; 95 \% \mathrm{CI}=1.09$ to $5.20 ; p=0.003)$ and history of birth weight $<2,500 \mathrm{~g}(\mathrm{~b}=1.70 ; 95 \% \mathrm{CI}=0.71$ to $2.70 ; \mathrm{p}=0.001)$ increased the risk of under nutrition in children under five. Slow fetal growth for gestational age, maternal gestational stress, family income $<\mathrm{Rp} 2,000,000$, and middle upper arm circumference (MUAC), had indirect significant effect on the risk of under nutrition in children under five.

Conclusion: Nutritional intake lower than recommended allowance and birth weight $<2,500 \mathrm{~g}$ increased the risk of under nutrition in children under five.
\end{abstract}

Keyword: gestational period, psychological and socio-economic exposure, under nutrition, children under five.

\section{Correspondence:}

Yespy Anna Wahyu Nurindahsari. School of Health Sciences Guna Bangsa, Yogyakarta.

\section{BACKGROUND}

Children underfive is a stage of child development which is susceptible to disease, including diseases that cause undernutrition or overnutrition (Kemenkes, 2015). Nutritional status of children under five influences body immunity, susceptibility to disease, as well as physical and mental growth and development. Good nutritional status is able to reduce the incidence of morbidity, disability, and mortality, therefore it will increase the quality of human resources (Kemenkes, 2013). Malnutrition problems in Indonesia include children underfive with undernutrition, stunting, protein energy malnutrition, vitamin A deficiency, and obesity (Kemenkes, 2013). The nutritional status of children underfive is measured by using the stunting prevalence number (height for age), underweight 
(weight for age) and wasting (weight for height) (Dewan Ketahanan Pangan, 2015).

The number of children under five with undernutrition and poor nutrition in Indonesia in 2013 was $19.6 \%$ and it was estimated that there were still 4.5 million under five with undernutrition and poor nutrition who had not detected yet. The nutritional status prevalence of children under five with poor nutrition and undernutrition in Indonesia was increased compared to 2007. The nutritional prevalence of children under five based on height/age and weight/age indicator, including shortthin, short-normal, and normal-fat was increased compared to 2010 (Kemenkes, 2013).

The mortality rate in Central Java Province in 2012 was $11.85 \%$, it was increased compared to 2011 (Dinas Kesehatan Provinsi Jawa Tengah, 2012). There was a total of $40 \%$ of children under five in rurals area who underwent stunted growth, The number of children who suffered in poverty was mostly concentrated in Central Java (UNICEF, 2012).

In Central Java Province, the causal factors of malnutrition among others are low maternal education, children under five with comorbidity, number of children in the family, children under five who are not exclusively breastfed, infant with Low Birth Weight (LBW) and infant who are not vaccinated (Novitasari, 2012).

Klaten district is one of districts in Central Java Province, where geographical factor, non-medical factor, and food intake cause the malnutrition in children under five (Dinkes Kabupaten Klaten, 2014; Kuntari et al, 2011). Based on preliminary survey conducted in Klaten District Health Office in February 2016, the number of children under five who were weighed in 34 community health care centers (Puskesmas) was 67,628. A total number of children under five with poor nutrition was 678 (1\%). A total number of children under five who were very short was 1.176 (1.7\%). A total number of children under five who were very thin was 63 (0.09\%) whereas the number of children under five who were fat was 2,230 (3.3\%). The data showed that the malnutrition was still high in Klaten district and the community participation to have their babies weighed in Posyandu was under $80 \%$.

Based on the elaboration above, there was no further study yet concerning the most dominant factors affecting malnutrition from prenatal period, in order to be able to take prevention efforts for malnutrition among children under five as early as possible.

This study aimed to analyze the effect of geographical area, nonmedical factor and psychological factor (stress exposure during gestational period) toward malnutrition in children under five.

\section{SUBJECTS AND METHOD}

The design of this study was analytical observational. The approach used was case control study. This study was conducted on 8 September to 2 December 2016 in Klaten district, Central Java. The independent variables were geographical area, nonmedical factor, and phychological factor (stress exposure during gestational period). The dependent variable was the malnutrition in children under five. A total of 150 subjects were selected by fixed exposure sampling, with a ratio of 1:2 between case and control group. The data were collected by a set of questionnaires, food recall questionnaires, and medical record (MCH book). The data were analyzed using logistic regression analysis with path analysis of STATA 13 program. 


\section{RESULTS}

1. Study Subject Characteristics

The results of the characteristics of the study subjects (Table 1) showed different distributions. The descriptions of the study subjects were described based on characteristics, criteria, frequency (n), and percent (\%).

Table 1. The Characteristics of the study Subject

\begin{tabular}{|c|c|c|}
\hline Characteristics & Case & Control \\
\hline Birth weight & $57(38 \%)$ & $93(62 \%)$ \\
\hline Sex Category & & \\
\hline Male & $18(31.58 \%)$ & $42(45.16 \%)$ \\
\hline Female & $39(68.42 \%)$ & $51(54.84 \%)$ \\
\hline Geographycal area & & \\
\hline Rural (Merapi slope, limestone hills) & $47(82.46 \%)$ & $73(78.49 \%)$ \\
\hline Urban & $10(17.54 \%)$ & $20(21.51 \%)$ \\
\hline Maternal Education & & \\
\hline Primary Education (<Senior High School) & $38(66.67 \%)$ & $43(46.24 \%)$ \\
\hline High Education ( $\geq$ Senior High School) & $19(33.33 \%)$ & $50(53.76 \%)$ \\
\hline Family Income & & \\
\hline$<\operatorname{Rp} 2,000,000$ & $49(86 \%)$ & $75(80.65 \%)$ \\
\hline$\geq \operatorname{Rp} 2,000,000$ & $8(14 \%)$ & $18(19.35 \%)$ \\
\hline
\end{tabular}

\section{Path Analysis}

Results of data processing using path analysis with the help of STATA 13 obtained the following results:

\section{a. Model Specification}

Model specifications illustrated the relationship between the variables studied. This study had variables that were measured (observed variable) namely geographical area, psychological factor during pregnancy, upper arm circumference (MUAC), fetal growth, birth weight, mother education, family income, number of children in the family, nutritional intake and malnutrition in children under five.

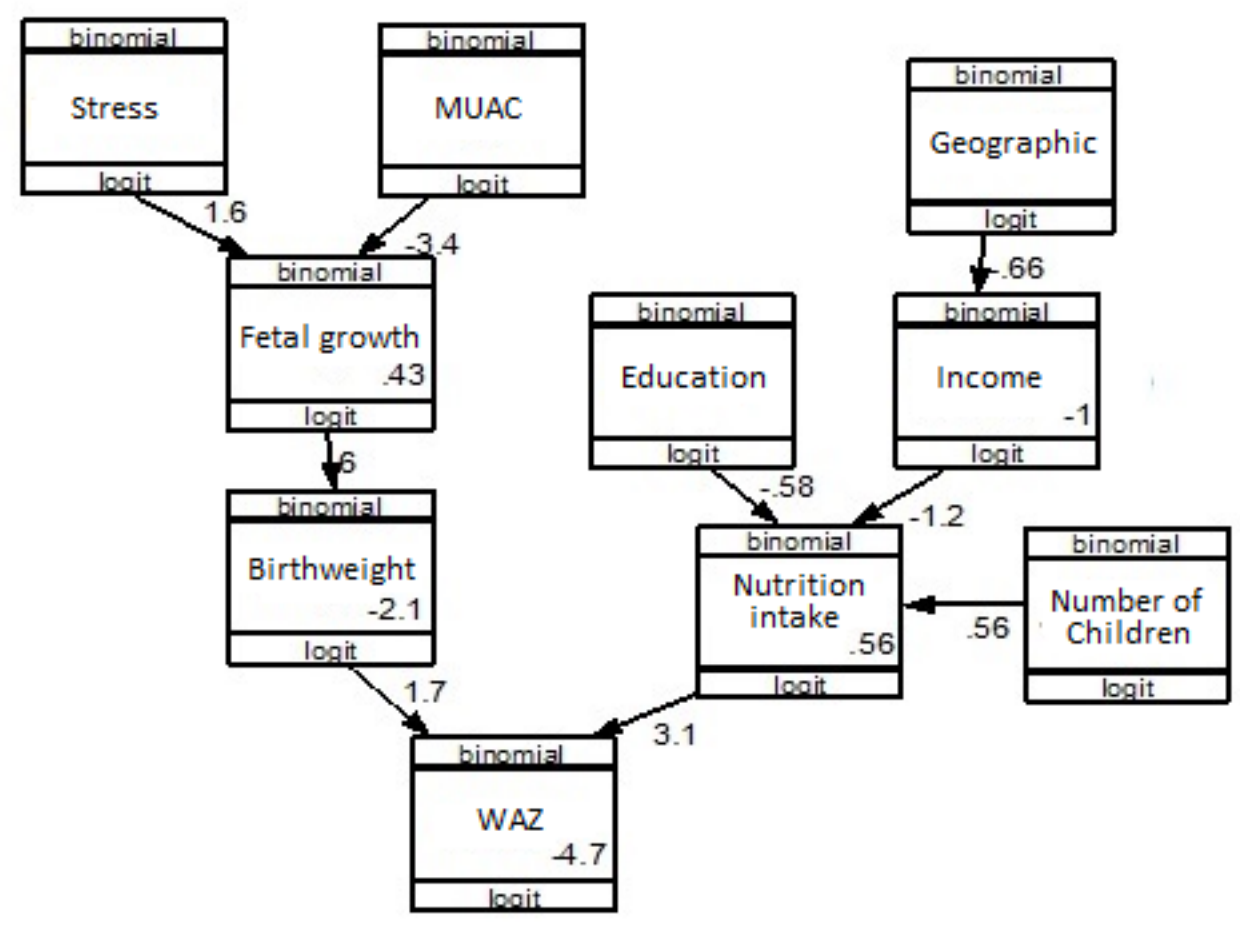

Figure 1. Structural model with path coefficient estimation 
Journal of Maternal and Child Health (2016), 1(2): 83-91

https://doi.org/10.26911/thejmch.2017.01.02.03

\section{b. Model Identification}

In this stage degree of freedom (df) was calculated which showed path analysis could be conducted or not, as shown below:

1) Total of measurable variables $\quad: 10$

2) Endogenous Variables $\quad: 5$

3) Exogenous Variables $\quad: 5$

4) Total of parameters : :9

The degree of freedom formulation was:

$\mathrm{df}=$ (total of measurable variables $\mathrm{x}$ (total of measurable variables +1$) / 2-($ Endogenous variables + Exogenous variables + total of parameters)

$$
\begin{aligned}
& =(10 \times 11) / 2-(5+5+9) \\
& =(110 / 2)-19 \\
& =55-19=36
\end{aligned}
$$

Path analysis could be conducted if $\mathrm{df} \geq 0$, while this model identification with path analysis obtained the df value as 36 (over identified) which mean path analysis could be conducted.

\section{c. The Model Fit and Parameter Estimation}

Picture 1 showed a structural model after the estimation by using STATA 13, as the value was shown on the picture. An indicator which showed conformity model of path analysis model as it was shown in table 2. The result of path analysis showed that there was a positive influence of nutrition intake toward malnutrition (weight/ age) children under five in Klaten District and was statistically significant. Children under five who received nutritional intake less than the average Recommended Dietary Allowance (RDA) had a logodd of Malnutrition (weight / age) 3.14 points higher than those with a high nutritional intake

\begin{tabular}{|c|c|c|c|c|c|c|}
\hline \multirow[b]{2}{*}{ Dependent Variable } & \multirow{2}{*}{\multicolumn{2}{|c|}{$\begin{array}{l}\text { Independent } \\
\text { Variable }\end{array}$}} & \multirow[b]{2}{*}{$\begin{array}{l}\text { Path } \\
\text { Coef. }\end{array}$} & \multicolumn{2}{|c|}{ 95\%CI } & \multirow[b]{2}{*}{$\mathbf{p}$} \\
\hline & & & & $\begin{array}{c}\text { Lower } \\
\text { limit }\end{array}$ & $\begin{array}{c}\text { Upper } \\
\text { limit }\end{array}$ & \\
\hline \multicolumn{7}{|l|}{ Direct Influence } \\
\hline Malnutrition (weight/age) & $\leftarrow$ & $\begin{array}{l}\text { Nutritional intake }< \\
\text { RDA }\end{array}$ & 3.14 & 1.09 & 5.20 & 0.003 \\
\hline $\begin{array}{l}\text { Malnutrition (weight/age) } \\
\text { Indirect Influence }\end{array}$ & $\leftarrow$ & Low Birth Weight & 1.70 & 0.71 & 2.70 & 0.001 \\
\hline Low Birth Weight & $\leftarrow$ & $\begin{array}{l}\text { Fetal Growth < } \\
\text { Gestational Period }\end{array}$ & 5.95 & 3.88 & 8.03 & $<0.001$ \\
\hline $\begin{array}{l}\text { Fetal Growth }< \\
\text { Gestational Period }\end{array}$ & $\leftarrow$ & Gestational stress & 1.60 & 0.53 & 2.66 & 0.003 \\
\hline $\begin{array}{l}\text { Fetal Growth < } \\
\text { Gestational Period }\end{array}$ & $\leftarrow$ & $\begin{array}{l}\text { middle upper arm } \\
\text { circumference }>23.5\end{array}$ & -3.35 & -4.40 & -2.31 & $<0.001$ \\
\hline $\begin{array}{l}\text { Nutritional intake }< \\
\text { RDA }\end{array}$ & & $\begin{array}{l}\text { Maternal education } \geq \\
\text { Senior School }\end{array}$ & -0.58 & -1.27 & 0.11 & 0.099 \\
\hline $\begin{array}{l}\text { Nutritional intake }< \\
\text { RDA }\end{array}$ & $\leftarrow$ & $\begin{array}{l}\text { Family Income }>\text { Rp } 2 \\
\text { million }\end{array}$ & -1.22 & -2.15 & -0.30 & 0.009 \\
\hline $\begin{array}{l}\text { Nutritional intake }< \\
\text { RDA }\end{array}$ & $\leftarrow$ & Number of children $>3$ & 0.56 & -0.19 & 1.31 & 0.148 \\
\hline $\begin{array}{l}\text { Family Income }>\text { Rp } 2 \\
\text { million } \\
\text { Likelihood }=-313.41 \\
\text { AIC }=654.82 \\
\text { BIC }=696.96\end{array}$ & $\leftarrow$ & Village residence & -0.65 & -1.61 & 0.29 & 0.172 \\
\hline
\end{tabular}
$(b=3.14 ; C I=1.09$ to $5.20 ; p=0.003)$.

Table 2. Path analysis result of weight on age

The results of path analysis showed that there was a positive effect between low birthweight to malnutrition (weight/Age) of children under five in Klaten District and 
was statistically significant. Children under five with low birthweight had a logodd malnutrition (weight/Age) of 1.70 points higher than children under five with normal birthweight $(b=1.70 ; C I=0.71$ to $2.70 ; p=$ o.001). Path analysis showed that there was an indirect association between fetal growths with malnutrition (weight/age) through birth weight and was statistically significant. Inappropriate/abnormal fetal growth according to the gestational age had a low birth weight logodd 5.95 points higher than pregnant women with appropriate/ normal fetal growth according gestational age $(b=5.95 ; 95 \% \quad C I=3.88$ to 8.03 ; $\mathrm{p}<0.001)$. Children under five with low birthweight generally had malnutrition logodd 1.70 points higher than children under five with normal birth weight $(b=$ $1.70 ; \mathrm{CI}=0.71$ to $2.70 ; \mathrm{p}=0.001$ ).

Path analysis showed that there was an indirect association between psychological factors with malnutrition (weight/ age) through fetal growth and birth weight and was statistically significant. Maternal psychological factors that are not good (stress) during pregnancy have an average low birth weight (LBW) logodd 1.60 points higher than mothers who were not stressed during pregnancy $(b=1.60 ; C I=0.53$ to 2.66; $\mathrm{p}=0.003)$. Inappropriate/abnormal fetal growth according to gestational age had a low birth weight logodd 5.95 points higher than in pregnant women with appropriate/normal fetal growth according gestational age. $(b=5.95 ; 95 \% \mathrm{CI}=3.88$ to 8.03; $\mathrm{p}<0.001)$. Children under five with underweight had a malnutrition logodd 1.70 points higher than children under five with normal birth weight $(b=1.70 ; C I=0.71$ to $2.70 ; \mathrm{p}=0.001$ ).

Path analysis showed that there was an indirect association between maternal MUAC and chilf malnutrition (WAZ) through fetal growth and birth weight and was statistically significant. The normal middle upper arm circumference generally had logodd of inappropriate fetal growth according to gestational age -3.35 points lower than in pregnant women with abnormal middle upper arm circumference. $(\mathrm{b}=$ $3.35 ; 95 \% \mathrm{CI}=-4.40$ to $-2.31 ; \mathrm{p}<0.001$ ). Inappropriate fetal growth according to gestational age had a low birth weight logodd 5.95 points higher than in pregnant women with appropriate fetal growth according gestational age $(b=5.95 ; 95 \% \mathrm{CI}=$ 3.88 to 8.03; $\mathrm{p}<0.001$ ). Children under five with low birth weight averagely had a malnutrition logodd (weight/age) 1.70 points higher than children under five with normal-birth weight $(b=1.70 ; 95 \% \mathrm{CI}=0.71$ to $2.70 ; \mathrm{p}=0.001$ ).

The results of path analysis showed that there was an indirect association between maternal education with malnutrition (weight/age) through nutritional intake and was statistically approaching to significant. High maternal education on average had a logodd of nutrient intake $<$ RDA -0.69 points lower than in mothers with low education $(b=-0.60 ; 95 \% \mathrm{CI}=$ 1.27 to $0.11 ; p=0.099)$. Children under five who received less than average RDA had a malnutrition logodd 3.14 points higher than those who received good nutrition $(b=3.14$; $95 \% \mathrm{CI}=1.09$ to $5.20 ; \mathrm{p}=0.003$ ).

Path analysis showed that there was an indirect association between family income and malnutrition (weight/age) through nutritional intake and statistically significant. Family income of more than 2 million rupiah per month on average had logodd of nutrition intake < RDA -1.23 points lower than in families with incomes less than 2 million rupiah per month $(\mathrm{b}=$ 1.23; $95 \% \mathrm{CI}=-2.15$ to $-0.30 ; \mathrm{p}=0.009)$. Children underfive who received less than average RDA had malnutrition logodd 3.14 points higher than those who received good 
nutrition $(b=3.14 ; 95 \% \mathrm{CI}=1.09$ to 5.20 ; $\mathrm{p}=0.003)$.

The results of path analysis showed that there was an indirect association between the numbers of children in the family with malnutrition (weight/age) through nutritional intake eventhough statistically insignificant. The number of children in the family of more than 3 people on average had a logodd of nutrition intake $<$ RDA 0.56 points higher than in families with children less than $3(b=-0.56 ; 95 \%$ $\mathrm{CI}=-0.20$ to $1.31 ; \mathrm{p}=0.148$ ). Children under five who received less than average RDA intake had malnutrition loggod 3.14 points higher than in children under five who received good nutritional intake $(b=$ $3.14 ; 95 \% \mathrm{CI}=1.09$ to $5.20 ; \mathrm{p}=0.003$ ).

Path analysis showed that there was an indirect association between geographic area with malnutrition through family income and nutritional intake even though statistically insignificant. Families living in villages on average had a logodd of income $>2$ million -0.66 lower than families living in the city $(b=-0.66 ; 95 \% \mathrm{CI}=-1.61$ to 0.29 ; $\mathrm{p}=0.172$ ). Family income of more than 2 million rupiah per month on average had a logodd of nutritional intake <RDA -1.23 points lower than in families with income less than 2 million rupiah per month $(b=-$ $1.23 ; 95 \% \mathrm{CI}=-2.15$ to $-0.30 ; \mathrm{p}=0.009$ ). Children under five who received less than average RDA intake had malnutrition logodd (weight / age) 3.14 points higher than children under five who received good nutritional intake $(\mathrm{b}=3.14 ; 95 \% \mathrm{CI}=1.09$ to $5.20 ; \mathrm{p}=0.003$ ).

\section{d. Respesification Model}

The model in this study was in accordance with the sample data as indicated by the saturation model and also the logistic regression coefficient which was more than zero and statistically significant, it was not necessary to recreate the path analysis model because it has obtained the model according to the sample data.

\section{DISCUSSION \\ 1. The effect of geographic area toward malnutrition in children under five}

The results showed that the geographical area affected malnutrition in children under five through income and nutrition intake. Families living in the urban area would have their income increased, as the increasing of family income the nutritional intake in children under five would be improving so it would decrease malnutrition.

These results are in accordance with Ayunin study (2012), geographical factors significantly affect the incidence of malnutrition in Ngawi District. It is important to analyze geographical factors toward the incidence of malnutrition due to the diversity of characteristics as well as the causes of nutritional status disparity among regions. This result is also in accordance with a study by Wigati (2009), that the geographical area directly or indirectly affects the diet of the community. In the mountain area the community seldom consume fish so that they are unfamiliar the food. Transportation affects food distribution in each region.

\section{The effect of maternal education toward malnutrition in children under five}

The results of this study indicated that maternal education affected malnutrition through nutritional intake. High maternal education would increase nutritional intake in children under five, so reducing the incidence of malnutrition. This study showed that there was an association between maternal education with nutritional intake and was statistically significant.

Maternal education affects malnutrition because it will affect the quality of 
parenting on children under five who are directly taken care of. Parenting on children under five will affect the quality and quantity of their food. The better the quality and quantity of their nutrition will reduce the incidence of malnutrition (Novita, 2012).

\section{The effect of family income toward malnutrition in children under five}

The results of this study indicated that family income affected malnutrition through nutritional intake. High family income would increase nutrition intake in children under five, so it reduced the incidence of malnutrition. This study showed that there was an association between family income with nutritional intake and statistically significant.

Families with high income on average can buy good quality of food in sufficient quantities. The food can improve the health of family members, especially children under five. Therefore there is an association between high family income and the improved nutritional status of children (Islam et al., 2014).

3. The effect of the number of children toward malnutrition in children under five

The results of this study indicated that the number of children affects malnutrition through nutritional intake. The number of children in the family would affect the distribution, quality and quantity of family nutrition. Families with large numbers of children would reduce nutritional intake of children under five. Less nutritional intake would increase the incidence of malnutrition.

This study is in accordance with Novitasari study (2012), that the number of children in the family affects the incidence of malnutrition. This is possible because the amount of available food is not sufficient in quality and quantity to be distributed to every member of the family. The more the number of family members the allocation of food for each individual in the family will be less.

\section{The effect of nutritional intake toward malnutrition in children under five}

The nutritional intake directly affected malnutrition and was statistically significant. Children under five who obtained good nutrition (according to the recommended dietary allowance by age) then the incidence of malnutrition would be reducing.

The individual nutritional affects the health of individuals and communities. Optimal nutrition intake affects the physical growth, development and intelligence of children under five. Good nutrition intake leads to normal weight and insusceptible body against infectious diseases. The results of basic health study (riskedas) in 2010 showed that nutritional intake has not been in accordance with balanced nutrition. The disparity includes low consumption of vegetables and fruits, low protein intake, foods and beverages are high in sugar and fat, low fluid consumption and low coverage of exclusive breastfeeding (Kemenkes, 2014).

\section{The effect of psychological factors during pregnancy toward mal- nutrition in children under five}

Psychological factors affects malnutrition in children under five through fetal growth and low birth weight and statistically significant. Mothers with good psychological condition during pregnancy increased the growth of the fetus in the womb. The fetus that growed well according to gestational period would lower the risk of LBW. Babies born with normal weight would reduce the risk of malnutrition.

This study is in accordance with Araujo et al. (2007) stress, anxiety and 
depression during pregnancy will trigger the increasing of hormone corticotropin, the increased secretion of this hormone will be followed by the increasing of hormone oxytocin and prostaglandin. This hormone causes uterine contractions that increase the risk of preterm birth so that the babies are born with.

\section{The effect of maternal MUAC during pregnancy against mal- nutrition in children under five}

The results of this study indicated that there was an effect of middle upper arm circumference (MUAC) during pregnancy toward the incidence of malnutrition in infants through fetal growth in uterine and low birth weight and statistically significant.

The most rapid fetal growth occurs in the third trimester. During this trimester maturation of the nervous system, digestion, immune and excretion occur.

This process will not run optimally if pregnant women experience Chronic Energy Deficiency (CED), because of nutritional supply defiency so baby will experience malnutrisi in the future (Newman, 2009).

\section{The effect of fetal growth toward malnutrition in children under five}

The growth of the fetus indirectly affected malnutrition through birth weight and statistically significant. Fetal growth is measured by the height of the uterine fundus adjusted for gestational period. If the growth of the fetus is good then the fundal height of uteri will enlarge according to the pregnancy period. Good fetal growth will lower the risk of LBW. When LBW risk is reducing then the risk of malnutrition will also be decreasing.

The influence of malnutrition since the fetus in the womb has an impact on the growth and physical development. The fetus grows by taking food from the mother, if the nutritional supply from the mother is not sufficient then the fetus will experience growth delay. The fetus who experiences delayed growth is at risk of birth with LBW who is also at risk of future malnutrition (Kemenkes, 2014).

\section{The effect of low birth weight to malnutrition in children under five} Low birth weight affected malnutrition. Low birth weight increased the risk of malnutrition. This study showed an effect and was statistically close to significant. This study is in accordance with the study of Kuntari et al. (2011) that children under five born under weight less than 2,500 grams are five times at risk of having malnutrition. Infants born less than 2,500 grams are susceptible to infectious diseases and chronic diseases (Pasricha, 2010). Infectious diseases such as diarrhea can cause malnutrition due to vomiting, fluid loss and decreased appetite (Ernawati, 2006).

Based on the results of the study, it can conclude that geographical area, psychological factor, maternal MUAC, fetal growth, birth weight, maternal education, family income, number of children, and nutritional intake are associated with malnutrition in children under five.

\section{REFERENCE}

Ayunin L, Sutikno (2012). Pemodelan Balita Gizi Buruk Di Kabupaten Ngawi Dengan Geographically Weighted Regression. Institute Teknologi Surabaya.

Dinas Kesehatan Kabupaten Klaten(2015). Info Kesehatan 2010-2014. Internet available from http://klatenkab.go.id/infrastruktur/kesehatan/.Diakses 29 Mei 2016.

Dinas Kesehatan Kabupaten Klaten (2015). Profil Kesehatan Kabupaten Klaten 
Tahun 2015. Dinas Kesehatan Kabupaten Klaten.

Dinas Kesehatan Provinsi Jawa Tengah (2012). Buku Profil Kesehatan Provinsi Jawa Tengah Tahun 2012. Dinas Kesehatan Provinsi Jawa Tengah.

Ditjen Bina Kesehatan Masyarakat, Kementerian Kesehatan Republik Indonesia. (2010). Peraturan Mentri Kesehatan Repuplik Indonesia tentang Penggunaan Kartu Menuju Sehat (KMS) bagi Balita.

Ernawati A (2006). Hubungan faktor sosial ekonomi, higiene sanitasi lingkungan, tingkat konsumsi dan infeksi dengan status gizi anak usia 2-5 tahun di Kabupaten Semarang. Semarang: Universitas Diponegoro;

Islam MS, Jothi JS, Islam M, Huq AKO (2014). Nutritional Status of Rural and Urban Under-Five Children in Tangail District, Bangladesh. International Journal of Innovation and Applied Studies ISSN 2028-9324, 8(2): 841-848.

Jamhari (2014). Bangsa Maju Karena Perempuan Cerdas. Jakarta: Kementerian Pendidikan dan Kebudayaan.

Kemenkes RI (2013). Riset Kesehatan Dasar 2013. Badan Penelitian dan Pengembangan Kesehatan.

Kemenkes RI (2015). Situasi dan Analisis Gizi. Pusat Data dan Informasi Kementerian Kesehatan Republik Indonesia.
Kemenkes RI (2015). Situasi Kesehatan Anak Balita di Indonesia. Pusat Data dan Informasi Kementerian Kesehatan Republik Indonesia.

Kemenkes RI, UNICEF (2013). Paket Konseling: Pemberian Makan Bayi dan Anak. Kementian Kesehatan Republik Indonesia.

Kuntari T, Jamil NA, Sunarto, Kurniati O (2011). Faktor Risiko Malnutrisi pada Balita. Jurnal Kesehatan Masyarakat, 7(12) Juli, 2013.

Kurniawan ES, Ratep N, Westa W (2013). Faktor Penyebab Depresi pada Ibu Hamil selama Asuhan Antenatal setiap Trimester. Universitas Udayana: SMF Psikiatri Fakultas Kedokteran.

Newman BM, Newman PR(2013). Development Through Life: A Pshycosocial Approach, Tenth Edition. USA: Wadsworth Cengage Learning.

Novitasari A(2012). Faktor - Faktor Risiko Kejadian Gizi Buruk Pada Balita Yang Dirawat Di Rsup Dr. Kariadi Semarang. Diakses dari http://eprints.undip.ac.id/37466/ pada 7 Juni 2016.

Wigati TR (2009). Fenomena Gizi Buruk pada Keluarga dengan Status Ekonomi Baik: Sebuah Studi tentang Negative Deviance di Indonesia. The Indonesian Journal of Public Health, 5(3): 89-93. 